\title{
ANALISIS TATA LUAS LAHAN DAN IKLIM TERHADAP PENGEMBANGAN TERNAK SAPI POTONG DI PULAU ENGGANO, BENGKULU UTARA
}

\author{
Yoki Panoga. ${ }^{1)}$, Dadang Suherman. ${ }^{2)}$, Bieng Brata. ${ }^{2)}$ \\ ${ }^{1}$ SMKN 2 Kota Bengkulu, Jl. Batang Hari Padang Harapan Kota Bengkulu \\ ${ }^{2}$ Jurusan Peternakan, Fakultas Pertanian, Universitas Bengkulu. \\ Jl. WR Supratman Kandang Limun Bengkulu
}

\begin{abstract}
ABSTRAK
Penelitian ini bertujuan untuk menganalisis daya dukung lahan dan daya dukung iklim terhadap perkembangan ternak sapi potong di Pulau Enggano. Penelitian dilakukan pada bulan Juli sampai dengan Agustus 2017 di Pulau Enggano yang memiliki ketinggian tempat \pm $5 \mathrm{~m}$ dpl. Data yang digunakan dalam penelitian adalah data sekunder. Data sekunder meliputi iklim yang diperoleh dari BMKG Pulau Baii. Data iklim yang digunakan dari tahun 2009 sampai dengan tahun 2016. Variabel iklim yang dianalisis dalam penelitian ini adalah suhu udara, kelembaban udara, lama penyinaran matahari, curah hujan, dan kecepatan angin. Variabel daya dukung lahan yang dianalisis adalah luas lahan sawah, sayuran, perkebunan, dan permukiman. Serta data perkembangan populasi sapi potong dari Dinas Peternakan Kabupaten Bengkulu Utara.Datayang dikumpulkan dianalisis secara deskriptif serta menggunakan analisis statistik regresi berganda. Hasil penelitian menunjukkan bahwa daya dukung lahan yang meliputi lahan sawah, sayuran, perkebunan, dan permukiman tidak berpengaruh terhadap populasi sapi potong. Faktor-faktor utama yang menopang populasi sapi potong di Pulau Enggano adalah kelembaban udara dan lama penyinaran matahari. Suhu udara, curah hujan, dan kecepatan angin tidak berpengaruh terhadap populasi sapi potong.
\end{abstract}

Kata Kunci : Tata Luas Lahan, Iklim, Sapi Potong, Pulau Enggano

\section{PENDAHULUAN}

Sektor peternakan menjadi salah satu andalan pembangunan nasional maupun regional dalam penyediaan lapangan kerja, peningkatan kesejahteraan masyarakat, mengurangi kemiskinan, penyediaan produksi kebutuhan pangan, dan perolehan devisa (Juanda, 2002). Pembangunan kawasan peternakan merupakan strategi umum untuk meningkatkan kesejahteraan peternak, meningkatkan daya saing produk pertanian serta menjaga kelestarian sumberdaya pertanian (Saragih, 2000). Untuk mewujudkan hal tersebut Pemerintah Daerah telah mendukung masyarakat serta stakeholder, terutama pada daerah potensial untuk pengembangan peternakan.

Pulau Enggano merupakan salah satu pulau terluar Negara Indonesia yang terletak di sebelah Barat Daya Pulau Sumatera, termasuk ke dalam wilayah
Kabupaten Bengkulu Utara, PropinsiBengkulu.Pulau tersebut memiliki luas areal sekitar 40.060hektar dengan sejumlah gugusan pulau kecil disekitarnya.Peruntukan luas lahan yang tersedia di Pulau Enggano meliputi 14.377,5 ha sebagai kawasan hutan, 1.258 ha sebagai lahan pertanian, dan $8.736,57$ Ha sebagai lahan konservasi.

Pulau Enggano masuk dalam wilayah Kabupaten Bengkulu Utara, yang berjarak 97 mil laut dari Kota Bengkulu dan dihuni oleh sekitar 130.000 jiwa, serta terdapat kawasan hutan lindung dan hutan produksi. Pulau Enggano Kabupaten Bengkulu Utara tersebut, dirancang sebagai sentra peternakan daerah. Komitmen menjadi sentra peternakan ditunjukkan dengan peningkatan anggaran bidang peternakan yaitu pada 2011 sebesar Rp5,9 miliar, pada tahun anggaran 2012 sebesar Rp11,2 miliar dan APDD Provinsi Bengkulu tahun 
anggaran 2013 meningkat menjadi Rp23,4 miliar (Musriadi, 2013).

Suhu dan kelembaban udara merupakan dua faktor iklim yang mempengaruhi produksi sapi, karena dapat menyebabkan perubahan keseimbangan panas dalam tubuh ternak, keseimbangan air, keseimbangan energi, dan keseimbangan tingkah laku ternak (Esmay 1982).McDowell (1974) menyatakan bahwa untuk kehidupan dan produksinya, ternak memerlukan suhu lingkungan yang optimum.Suhu lingkungan berhubungan dengan ketinggian suatu tempat. Menurut Pane (1970), semakin tinggi letak daerah dari permukaan laut maka akan semakin rendah suhu udara hariannya.

Ternak biasanya memperlihatkan kondisi fisik optimal jika memiliki sifat genetik unggul dan didukung kesesuaian lingkungan tempat ternak tumbuh. Faktor lingkungan berpengaruh pula terhadap pertumbuhan ternak, antara lain adalah suhu, penyinaran matahari, dan kelembaban udara (Silanikove 2000). Kadarsih (2004) menambahkan bahwa perbedaan ketinggian tempat berpengaruh terhadap performan sapi. Faktor-faktor tersebut merupakan faktor yang mempengaruhi produksi dan produktivitas ternak. Jika ternak dipelihara pada suatu wilayah yang tidak sesuai dengan kondisi fisiologis ternak, maka produksi dan produktivitasnya dapat menurun. Berdasarkan uraian pada latar belakang, maka dapat diidentifikasikan rumusan masalah dalam penelitian ini adalah; Seberapa besar pengaruh tata luas lahan di Pulau Enggano untuk perkembangan sapi potong? Seberapa besar pengaruh iklim di Pulau Enggano untuk perkembangan sapi potong? Penelitian ini bertujuan untuk; Menganalisis pengaruh tata luas lahan terhadap perkembangan ternak ruminansia di Pulau Enggano. Menganalisis pengaruh iklim terhadap perkembangan ternak ruminansia di Pulau Enggano.

\section{METODE PENELITIAN}

\section{Waktu dan Tempat Penelitian}

Penelitian dilakukan pada Juli sampai dengan Agustus 2017 di Pulau Enggano yang memiliki ketinggian tempat $\pm 5 \mathrm{~m} \mathrm{dpl}$ (meter diatas permukaan laut) dengan luas kawasan

\section{Metode Pengumpulan Data}

Data yang dikumpulkan dalam penelitian berupa data sekunder.Data sekunder meliputi iklim yang diperoleh dari Badan Meteorologi Klimatologi dan Geofisika (BMKG) Pulau Baii.Data iklim yang dikumpulkan dari tahun 2009 sampai dengan tahun 2016. Luas lahan dan populasi sapi potong didapat dari Badan Pusat Statistik (BPS) Bengkulu Utara dari tahun 2009 sampai dengan tahun 2016.

\section{Variabel yang Diamati}

Variabel luas lahan yang diamati adalah : Luas lahan sawah, Luas lahan sayuran, Luas lahan perkebunan, Luas kawasan permukiman

Variabel iklim yang diukur adalah : Suhu Udara, Kelembaban Udara, Lama Penyinaran Matahari, Curah Hujan, Kecepatan Angin.

\section{Analisis Data}

Data luas lahan, iklim, dan jumlah populasi ternak sapi potong di Pulau Enggano dianalisis menggunakan analisis regresi berganda. Selanjutnya untuk melihat pengaruh masing-masing variabel penelitian terhadap daya dukung lingkungan untuk populasi di lakukan uji $\mathrm{t}$ paired. Adapun persamaan regresi berganda yang digunakan adalah :

1. Analisis hubungan tata luas lahan dengan populasi sapi potong dilakukan dengan model persamaan :

$$
Y=a+c_{1} X_{1}+c_{2} X_{2}+c_{3} X_{3}+c_{4} X_{4}
$$

Keterangan :

$\mathrm{Y}=$ Jumlah Populasi Sapi Potong

$\mathrm{X}_{1}=$ Luas lahan sawah

$\mathrm{X}_{2}=$ Luas lahan sayuran

$\mathrm{X}_{3}=$ Luas lahan perkebunan

$\mathrm{X}_{4}=$ Luas kawasan permukiman 
$\alpha=$ Koefisien Intercept (konstantan)

$\mathrm{c}_{1}, \mathrm{c}_{2}, \mathrm{c}_{3}, \mathrm{c}_{4}=$ koefisisen regresi

2. Analisis hubungan daya dukung iklim dengan populasi sapi potong dilakukan dengan model persamaan :

$$
\begin{gathered}
Y=a+b_{1} X_{1}+b_{2} X_{2}+b_{3} X_{3}+b_{4} X_{4} \\
+b_{5} X_{5}
\end{gathered}
$$

Keterangan :

$$
\begin{aligned}
& Y=\text { Jumlah Populasi Sapi Potong } \\
& X_{1}=\text { Suhu Udara } \\
& X_{2}=\text { Kelembaban Udara } \\
& X_{3}=\text { Lama Penyinaran Matahari } \\
& X_{4}=\text { Curah Hujan } \\
& X_{5}=\text { Kecepatan Angin } \\
& a=\text { Koefisien Intercept (konstantan) } \\
& b_{1}, b_{2}, b_{3}, b_{4}, b_{5}=\text { koefisisen regresi }
\end{aligned}
$$

\section{HASIL DAN PEMBAHASAN}

Penduduk asli Pulau Enggano adalah Suku Enggano, yang terbagi menjadi lima puak asli (penduduk setempat menyebutnya $s u k u$ ). Semuanya berbahasa sama, bahasa Enggano. Suku atau Puak Kauno yang mulai menempati tempat ini pada zaman Belanda (sekitar tahun 1934). Selain Suku Kauno, terdapat Suku Banten (pendatang), dan empat suku lainnya. Suku Enggano memakai Bahasa Enggano dalam percakapan sehari hari.

Mata pencaharian utama masyarakat di Pulau Enggano adalah petani dan nelayan.Pekerjaan lainnya adalah pegawai swasta, pengusaha dan pegawai negeri. Perkebunan yang dikembangkan merupakan jenis perkebunan rakyat jenis cokelat, melinjo, cengkeh, kelapa, buahbuahan dan kopi. Hasil dari perkebunan itu mereka jual ke Kota Bengkulu.Selain itu untuk memenuhi kebutuhan hidup seharihari masyarakat di Pulu Enggano mengelola peternakan kerbau, sapi, kambing, ayam dan itik.

\section{Populasi Ternak Sapi Potong Di Pulau Enggano}

Populasi sapi potong di Pulau enggano dari tahun 2009 sampai 2016 tersaji pada Gambar 2.

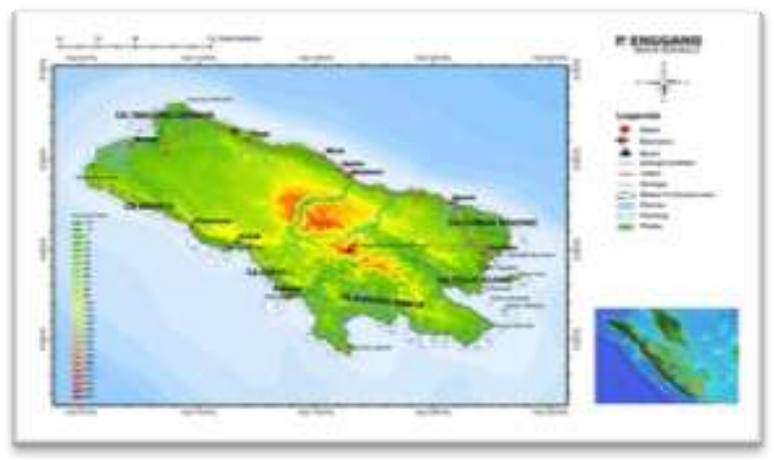

Gambar 1. Peta Pulau Enggano Kabupaten Bengkulu Tengah

Hasil analisis pada Gambar tersebut menunjukkan bahwa jumlah populasi sapi di pulau Engano terjadi peningkatan. Tahun 2009 populasi sapi di Pulau Enggano sebesar 79 ekor dan mengalami peningkatan pada 2010 menjadi 83 ekor. Peningkatan juga terjadi pada tahun 2011 sampai dengan 2015. Populasi sapi di Pulau Enggano tahun 2011-2015 secara berturut-turut 102 ekor, 142 ekor, 248 ekor, 248 ekor, dan 295 ekor. Sementara itu pada tahun 2016 populasi sapi mengalami penurunan menjadi 207 ekor.

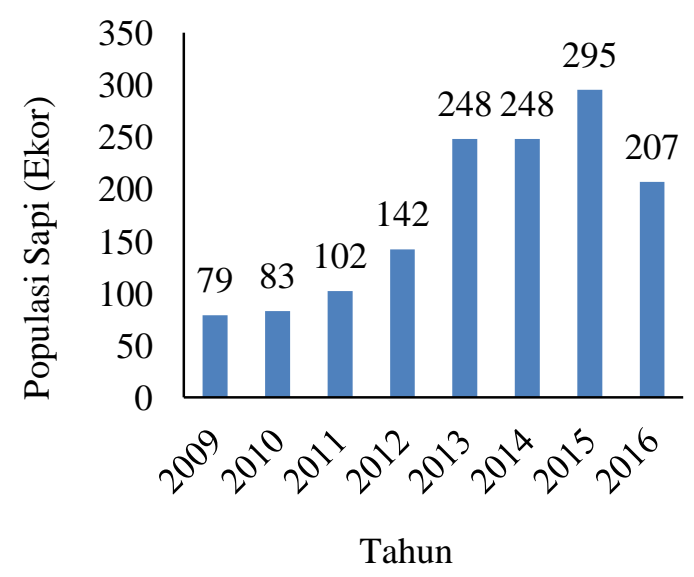

Gambar 2. Populasi sapi di Pulau Enggano Kabupaten Bengkulu Utara tahun 2009-2016

Perkembangan sapi potong di pulau Enggano mengalami fluktuasi. Tingkat perkembangan tertinggi populasi sapi terjadi pada tahun 2013 sebesar 74,65\%, serta terrendah pada tahun 2014 sebesar $0 \%$ hal tersebut karena populasi sapi pada 
2014 sama dengan populasi sapi 2015. Peningkatan tersebut diduga sebagai akibat dari keseriusan pemerintah dalam mengembangkan sapi di pulai Enggano. Musriadi (2013) menyatakan bahwa komitmen menjadi sentra peternakan ditunjukkan dengan peningkatan anggaran bidang peternakan pada 2011 sebesar Rp5,9 miliar, pada tahun anggaran 2012 sebesar Rp11,2 miliar, dan APBD Provinsi Bengkulu tahun anggaran 2013 meningkat menjadi Rp23,4 miliar. Akan tetapi pada tahun 2016 populasi sapi mengalami penurunan sebesar $29,83 \%$. Hal tersebut diakibatkan meningkatnya jumlah penduduk yang diikuti dengan peningkatan kawasan permukiman, yang berdampak pada peningkatan lahan yang diusahakan oleh masyarakat, baik sebagai tempat tinggal maupun usaha pertanian. Peningkatan luas lahan pemukiman, pertanian, dan perkebunan mengakibatkan penurunan luas lahan padang pengembalaan akibatnya rumput untuk pakan ternak menjadi rendah.

\section{Luas Lahan Di Pulau Enggano}

Daya dukung lahan merupakan salah satu faktor penting dalam pengembangan sapi disuatu daerah.Lahan berkontribusi besar dalam pengembangan ternak baik menyediakan lahan untuk bertempat tinggal maupun mencari makan.Daya dukung lahan yang diteliti meliputi luas lahan sawah, lahan sayuran, lahan perkebunan, dan kawasan permukiman selama kurun waktu 2009-2016 disajikan pada Tabel 1.

\section{Keadaan Iklim Di Pulau Enggano}

Iklim merupakan salah satu faktor penting dalam mengembangkan ternak sapi. Dalam penelitian ini data iklim diperoleh dari BMKG Pulau Baii, Kota Bengkulu. Rata-rata iklim di pulau Enggano dari tahun 2009-2016 disajikan pada Gambar 4-8

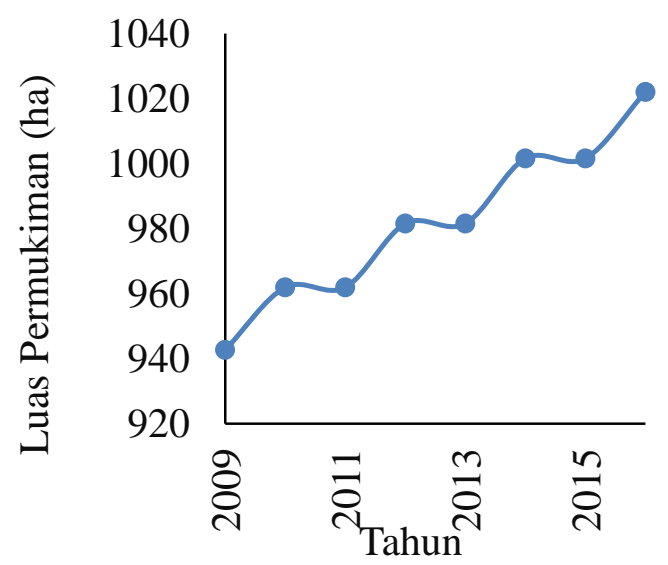

Gambar 3. Luas kawasan permukiman di Pulau Enggano Kabupaten Bengkulu Utara tahun 2009-2016

\section{Suhu Udara}

Hasil analisis pada Gambar 4 menunjukkan bahwa rata-rata suhu udara selama 7 tahun (2009-2016) cenderung mengalami peningkatan. Rata-rata suhu udara tahun 2016 cenderung lebih tinggi dari tahuntahun sebelumnya yaitu sebesar $27,15{ }^{0} \mathrm{C}$, sedangkan rata-rata suhu udara tahun 2009 cenderung lebih rendah dari suhu udara di tahun 2010-2016 yaitu sebesar $26,59{ }^{\circ} \mathrm{C}$.

Tabel 1. Luas lahan sawah, sayuran, perkebunan, dan permukiman di Pulau Enggano tahun 2009-2016

\begin{tabular}{ccccc}
\hline \multirow{2}{*}{ Tahun } & \multicolumn{4}{c}{ Luas Lahan (ha) } \\
\cline { 2 - 5 } & Sawah & Sayuran & Perkebunan & Permukiman \\
\hline 2009 & 325 & 52 & 2239 & 943 \\
2010 & 431 & 53 & 2284 & 962 \\
2011 & 243 & 55 & 2284 & 962 \\
2012 & 604 & 56 & 2331 & 982 \\
2013 & 686 & 57 & 2331 & 982 \\
2014 & 788 & 58 & 2378 & 1002 \\
2015 & 671 & 113 & 2378 & 1002 \\
2016 & 684 & 115 & 2427 & 1022 \\
\hline
\end{tabular}




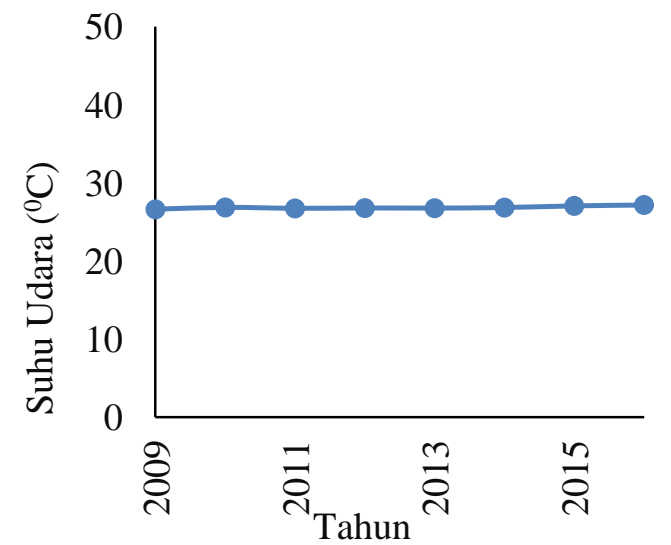

Gambar 4. Rata-rata suhu udara di Pulau Enggano Kabupaten Bengkulu Utara tahun 2009-2016

\section{Kelembaban Udara}

Hasil analisis pada Gambar 5 menunjukkan bahwa rata-rata kelembaban udara selama 7 tahun (2009-2016) cenderung sama. Rata-rata kelembaban udara tahun 2010 cenderung lebih tinggi yaitu sebesar $84,50 \%$, sedangkan rata-rata kelembaban udara tahun 2011 dan 2012 cenderung lebih rendah yaitu sebesar $83,11 \%$.

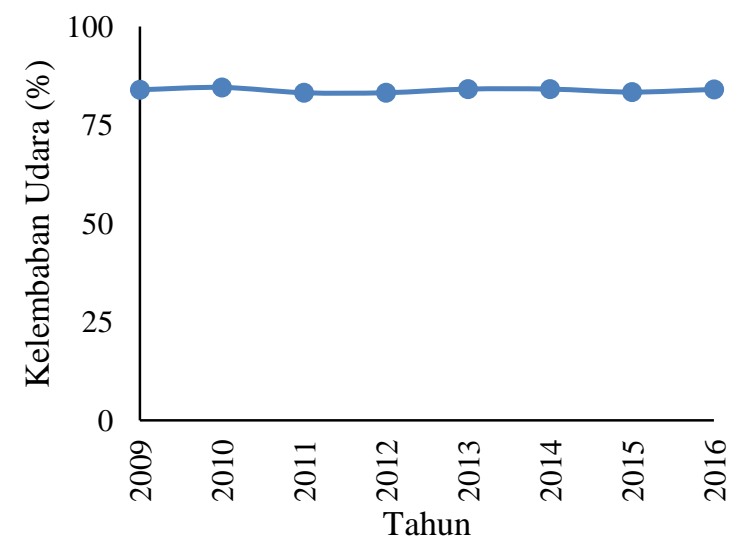

Gambar 5. Rata-rata kelembaban udara di Pulau Enggano Kabupaten Bengkulu Utara tahun 2009-2016

\section{Lama Penyinaran Matahari}

Hasil analisis pada Gambar 6 menunjukkan bahwa rata-rata lama penyinaran matahari selama 10 tahun (2009-2016) mengalami fluktuasi. Ratarata lama penyinaran matahari pada 2009 sebesar 67,85\%, mengalami penurunan pada 2010 menjadi 63,42\%. Pada 2011 dan 2012 lama penyinaran matahari meningkat menjadi $68 \%$ dan $69,33 \%$. Namun pada 2013 dan 2014 menurun menjadi $67,58 \%$ dan $68 \%$. Pada 2015 lama penyinaran matahari kembali meningkat menjadi $71,67 \%$, akan tetapi kembali menurun pada 2016 menjadi 66,17\%.

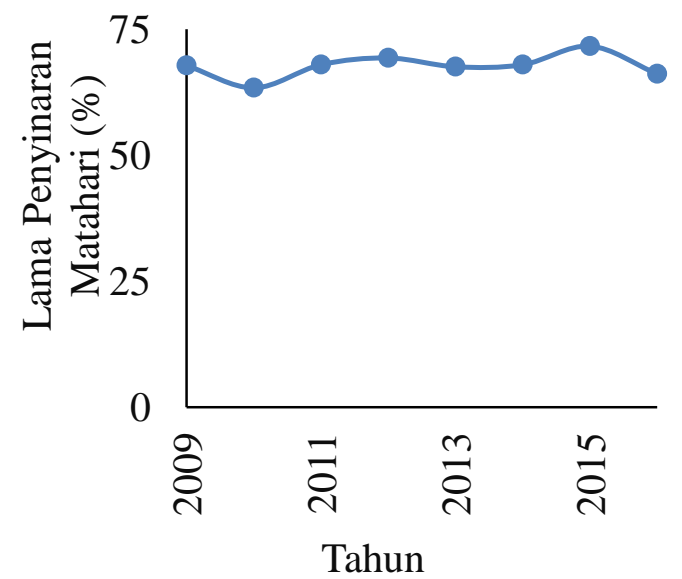

Gambar 6. Rata-rata lama penyinaran matahari di Pulau Enggano Kabupaten Bengkulu Utara tahun 2009-2016

\section{Curah Hujan}

Hasil analisis pada Gambar 7 menunjukkan bahwa rata-rata curah hujan selama 7 tahun (2009-2016) mengalami fluktuasi. Rata-rata curah hujan tahun 2009 sebesar 564,67 mm, sedangkan rata-rata curah hujan tahun 2011 cenderung lebih rendah yaitu sebesar 168,58 $\mathrm{mm}$. mengalami penurunan pada 2010 dan 2011 menjadi $496,25 \mathrm{~mm}$ dan $168,58 \mathrm{~mm}$.

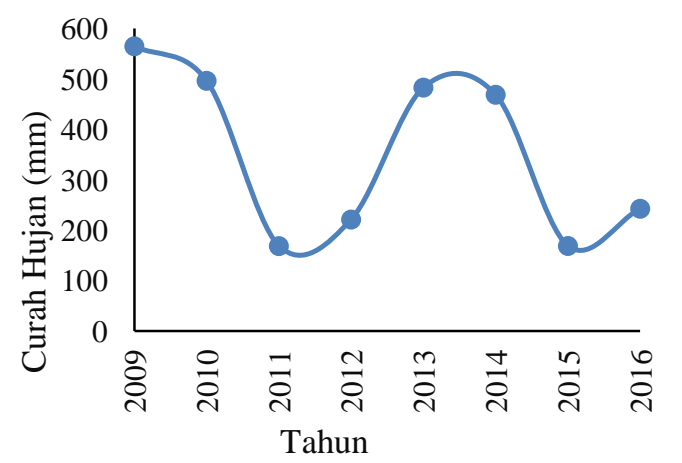

Gambar 7. Rata-rata curah hujan di Pulau Enggano Kabupaten Bengkulu Utara tahun 2009-2016 
Pada 2012 dan 2013 curah hujan di Pulau Enggano meningkat menjadi $221,17 \mathrm{~mm}$ dan 482,75 mm, namun kembali menurun pada 2014 dan 2015 menjadi $468 \mathrm{~mm}$ dan $168 \mathrm{~mm}$. Pada 2016 curah hujan cenderung meningkat menjadi $242,58 \mathrm{~mm}$

\section{Kecepatan Angin}

Hasil analisis pada Gambar 8 menunjukkan bahwa rata-rata kecepatan angin selama 7 tahun (2009-2016) mengalami fluktuasi. Rata-rata kecepatan angin pada 2009 sebesar 5,25 knot, meningkat menjadi 5,67 knot dan 9,33 knot pada 2010 dan 2011. Namun kecepatan angin mengalami penurunan pada 20122012 dan 2013 menjadi 3,92 knot dan 3,42 knot. Pada 2014 dan 2015 kecepatan angin cenderung mengalami peningkatan menjadi 4,00 knot dan 4,33 knot, akan tetapi kembali cenderung menurun pada 2016 menjadi 4,17 knot.

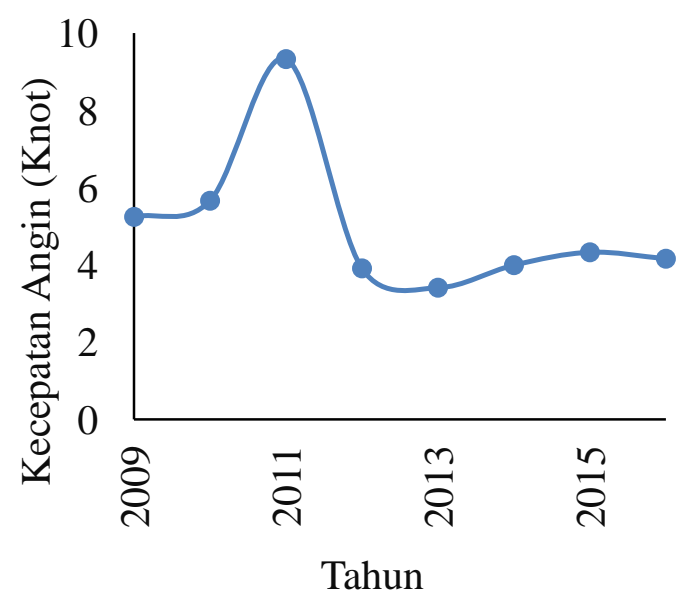

Gambar 8. Rata-rata kecepatan angin di Pulau Enggano Kabupaten Bengkulu Utara tahun 2009-2016

\section{Regresi Tata Luas Lahan Terhadap Ternak Sapi Potong}

Analisis tata luas lahan yang meliputi luas lahan sawah, sayuran, perkebunan, dan pemukiman terhadap populasi sapi disajikan pada Tabel 2.Berdasarkan Tabel 2 terlihat bahwa nilai Adjusted R Square adalah sebesar 0.560, bearti bahwa populasi sapi di Pulau Enggao dipengaruhi oleh tata luas lahan (luas lahan sawah, sayuran, perkebunan dan pemukiman) sebasar 56\%. Sebesar $44 \%$ dipengaruhi oleh faktor-faktor lain yang tidak diteliti dalam penelitian.

Tabel 2. Hasil analisis pengaruh tata luas lahan terhadap populasi sapi di Pulau Enggano Kabupaten Bengkulu Utara

\begin{tabular}{llc}
\multicolumn{1}{c}{ Varians } & Nilai \\
\hline $\mathrm{R}$ & & 0.901 \\
$\mathrm{R}$ Square & & 0.812 \\
Adjusted & $\mathrm{R}$ & 0.560 \\
Square & &
\end{tabular}

Square

Std. Error of the $\quad 56.14$

Estimate

Pengaruh variabel bebas yaitu daya dukung lahan (luas lahan sawah, sayuran, perkebunan dan pemukiman) terhadap variabel terikat (populasi sapi) serta besarnya pengaruh masing-masingvariabel bebas terhadap variabel terikat dapat dilihat dari perhitungan regresi linier berganda pada Tabel 3 .

Berdasarkan hasil analisis regresi linear berganda yang tertera pada Tabel 3 menunjukkan bahwa secara statistik antara variabe bebas dan variabel terikat tidak berhubungan yang nyata. Bentuk persamaan regresi hubungan variabel bebas (luas lahan sawah, sayuran, perkebunan dan pemukiman) terhadap variabel terikat (populasi sapi) mengasilkan model persamaan $\mathrm{Y}=$ $867,532+0,432 X_{1}+1,643 X_{2}-61,141 X_{3}$ $+13,44 \mathrm{X}_{4}$.

\section{Hubungan Secara Parsial Luas Sawah terhadap Daya Dukungl Lahan untuk Sapi Potong}

Hubungan luas lahan sawah terhadap daya dukung lahan untuk peternakan sapi di Pulau Enggano dari hasil analisis perhitungan regresi linier ganda tersaji pada Tabel4. Berdasarkan hasil analisis terlihat bahwa nilai $\mathrm{p}$ sig $0,186>\alpha(0,05)$. Hal tersebut menunjukkan bahwa luas lahan sawah tidak berpengaruh nyata terhadap daya dukung lahan bagi peternakan sapi potong di Pulau Enggano. Hasil yang berbeda diperoleh pada penelitian Matondang dkk (1998) bahwa luas sawah berpengaruh 
Tabel 3. Hasil analisis regresi hubungan luas lahan terhadap populasi sapi di Pulau Enggano Kabupaten Bengkulu Utara

\begin{tabular}{|c|c|c|c|c|c|}
\hline \multirow[t]{2}{*}{ Model } & \multicolumn{2}{|c|}{ Unstandardized Coefficients } & \multirow{2}{*}{$\begin{array}{c}\text { Standardized } \\
\text { Coefficients }\end{array}$} & \multirow[t]{2}{*}{$\mathrm{t}$} & \multirow[t]{2}{*}{ Sig. } \\
\hline & $\mathrm{B}$ & Std. Error & & & \\
\hline (Constant) & 867.532 & 2236.07 & & 0.388 & 0.724 \\
\hline Sawah (X1) & 0.432 & 0.252 & 1.001 & 1.711 & 0.186 \\
\hline Sayuran (X2) & 1.643 & 1.642 & 0.530 & 1.000 & 0.391 \\
\hline Perkebunan (X3) & -61.141 & 117.588 & -4.574 & -0.520 & 0.639 \\
\hline Pemukiman (X4) & 13.448 & 27.512 & 4.125 & 0.489 & 0.658 \\
\hline
\end{tabular}

nyata terhadap populasi sapi potong di Lampung. Hasil yang berbeda ini diduga karena kebiasaan petani tidak memanfaatkan jerami padi atau residu padi lainnya sebagai bahan pakan sapi potong, melainkan untuk peruntukan lain, seperti dibakar atau ditebar ke sawah sebagai bahan kompos.

Berdasarkan model persamaan regresi linier dapat dijelaskan bahwa nilai $\beta$ sebesar 1,001 bernilai positif, hal tersebut menunjukkan bahwa semakin luas lahan sawah, maka akan naik semakin tinggi pula tingkat daya dukung lahannya terhadap perkembangan peternakan sapi potong, yaitu jika luas sawah naik 1 satuan ha lebih tinggi, maka tidak berpengaruh nyata tingkat daya dukung lingkungan atau prosentase sapi potong yang berhasil diternakkan akan naik $1,001 \%$, tetapi tidak berpengaruh nyata.

\section{Hubungan luas lahan sayuran terhadap daya dukung lahan untuk sapi potong}

Pengaruh luas lahan sayuran terhadap daya dukung lahan untuk peternakan sapi di Pulau Enggano dapat dilihat dari hasil perhitungan regresi linier ganda pada Tabel 4. Berdasarkan hasil analisis regresi linier ganda dapat dilihat bahwa nilai $p$ sig $0,391>\alpha(0,05)$. Hal tersebut menunjukkan bahwa luas lahan sayuran tidak berpengaruh nyata terhadap daya dukung lahan bagi peternakan sapi potong di Pulau Enggano. Sejalan dengan hasil penelitian Sukada dkk (2016) bahwa hubungan antara lahan sayuran (hortikultural) (X) terhadappopulasi sapi potong (Y) tidak berbeda nyata.

Berdasarkan model persamaan regresi linier dapat dijelaskan bahwa nilai $\beta$ sebesar 0,53 bernilai positif, hal tersebut menunjukkan bahwa semakin luas lahan sayuran, maka akan naik semakin tinggi pula tingkat daya dukung lahannya terhadap perkembangan peternakan sapi potong,yaitu jika luas lahan sayuran naik 1ha lebih tinggi, maka tidak berpengaruh nyata tingkat daya dukung lingkungan atau prosentase sapi potong yang berhasil diternakkan akan naik $0,53 \%$, tetapi tidak berpengaruh nyata.

\section{Hubungan luas perkebunan terhadap daya dukung lahan untuksapi potong}

Pengaruh luas perkebunan terhadap daya dukunglahan untuk peternakan sapi di Pulau Enggano dapat dilihat dari hasil perhitungan regresi linier ganda pada Tabel 4. Berdasarkan hasil analisis regresi linier ganda dapat dilihat bahwa nilai $p$ sig $0,639>\alpha(0,05)$. Hal tersebut menunjukkan bahwa luas perkebunan tidak berpengaruh nyata terhadap daya dukung lahan bagi peternakan sapi potong di Pulau Enggano. Hasil berbeda didapat pada penelitian Sukada dkk (2016) bahwa populasi ternak potong terhadap lahan perkebunan berhubungan positif sangat nyata. Peningkatan luas lahan perkebunan mengakibatkan penurunan populasi sapi potong. Berdasarkanmodelpersamaan 
Regresi linier dapat dijelaskan bahwa nilai $\beta$ sebesar 4,574 bernilai negatif, hal tersebut menunjukkan bahwa semakin luas perkebunan, maka tidak berpengaruh nyata semakin rendah tingkat daya dukung lahannya terhadap perkembangan peternakan sapi potong, yaitu jika luas perkebunan naik 1 satuan ha lebih tinggi, maka tidak berpengaruh nyata tingkat daya dukung lingkungan atau prosentase sapi potong yang berhasil diternakkan akan menurun $4,574 \%$.

\section{Hubunganluas \\ pemukimanterhadapdaya dukunglahanuntuksapipotong}

Pengaruh luas pemukiman terhadap daya dukung lahan untuk peternakan sapi di Pulau Enggano dapat dilihat dari hasil perhitungan regresi linier ganda pada Tabel5. Berdasarkan hasil analisis regresi linier ganda dapat dilihat bahwa nilai $p$ sig $0,658>\alpha(0,05)$. Hal tersebut menunjukkan bahwa luas pemukiman tidak berpengaruh nyata terhadap daya dukung lahan bagipeternakansapi potongdi Pulau Enggano.

Berdasarkan model persamaan regresi linier dapat dijelaskan bahwa nilai $\beta$ sebesar 4,125 bernilai positif, hal tersebut menunjukkan bahwa semakin luas pemukiman, maka akan naik semakin tinggi pula tingkat daya dukung lahannya terhadap perkembangan peternakan sapi potong,yaitu jika luaspemukiman naik1 satuan ha lebih tinggi, maka tingkat daya dukung lingkungan atau prosentase sapi potong yang berhasil diternakkan akan naik $4,125 \%$.

\section{Faktor-faktor yang menopang daya dukung lahan terhadap populasi sapi potong}

Secara umum hasil penelitian menunjukkan bahwa luas lahan sawah, lahan sayuran, lahan perkebunan, dan kawasan permukiman tidak berpengaruh terhadap populasi sapi potong. Hal ini diduga karena pada kawasan lahan tersebut telah diusahakan oleh penduduk baik untuk budidaya maupun pertanian, sehingga rumput yang menjadi pakan sapi potong tidak tersedia. Menurut Sofyan (2003) bahwa hijauan pakan ternak yang dipergunakan oleh ternak ruminansia sebagian besar rumput- rumputan, sehingga rumput memegang peranan penting dalam penyediaan pakan dan telah umum digunakan oleh peternak dalam jumlah besar. Oleh karena itu pengembangan sapi potong pada kawasan ini, harus melalui upaya peningkatan, baik potensi lahan maupun sumberdaya manusianya. Menurut Sumarjono etal. (2008), pengembangan sapi potong dapat dilakukan melalui peningkatan potensi lahan, sumber daya manusia, pakan dan pola pakan.

\section{Regresi Daya Dukung Iklim Terhadap Populasi Sapi}

Pengaruh daya dukung iklim yang meliputi kecepatan angin, lama penyinaran matahari, suhu udara, kelembaban udara dan curah hujan terhadap populasi sapi disajikan pada Tabel 4.

Tabel 4. Hasil analisis pengaruh daya dukung iklim terhadap populasi sapi di Pulau Enggano Kabupaten Bengkulu Utara

\begin{tabular}{lc}
\hline \multicolumn{1}{c}{ Varians } & Nilai \\
\hline $\mathrm{R}$ & 0.982 \\
$\mathrm{R}$ Square & 0.965 \\
Adjusted R Square & 0.878 \\
Std. Error of the & 29.52569 \\
Estimate & \\
\hline
\end{tabular}

Berdasarkan Tabel 4 terlihat bahwa nilai Adjusted $\mathrm{R}$ Square adalah sebesar 0,878 yang bearti bahwa populasi sapi di Pulau Enggano dipengaruhi oleh daya dukung lahan (kecepatan angin, lama penyinaran matahari, suhu udara, kelembaban udara dan curah hujan) sebesar $87,8 \%$. Sedangkan 12,2\% dipengaruhi oleh faktor-faktor lain yang tidak diteliti dalam penelitian ini.

Pengaruh antara variable bebas (kecepatan angin, lama penyinaran matahari, suhu udara, kelembaban udara 
dan curah hujan) terhadap variabel terikat (populasi sapi) dan besarnya pengaruh masing-masingvariabel bebas terhadap variabel terikat dapatdilihat dari perhitungan regresi linier bergandapada Tabel 5.Berdasarkan analisis regresi berganda pada Tabel 5.maka didapat bentuk persamaan regresi hubungan variabel bebas (kecepatan angin, lama penyinaran matahari, suhu udara, kelembaban udara dan curah hujan) terhadap populasi sapi yaitu $\mathrm{Y}=-15538,74$ $+52,14 X_{1}+139,95 X_{2}+39,27 X_{3}+$ $0,005 X_{4}-1,34 X_{5}$. Secara statistik kelembaban udara dan lama penyinaran matahari berpengaruh nyata terhadap populasi sapi potong, sedangkan suhu udara, curah hujan, dan kecepatan angin tidak berpengaruh nyata terhadap populasi sapi potong.

\section{Hubungan suhu udara terhadap daya dukung iklim untuk sapi potong}

Pengaruh suhu udara terhadap daya dukung iklim untuk peternakan sapi di Pulau Enggano dapat dilihat dari hasil perhitungan regresi linier ganda pada Tabel 5. Berdasarkanhasil analisis regresi linier ganda dapat dilihat bahwa nilai $\mathrm{p}$ sig $0,25>\alpha(0,05)$.

Hal tersebut menunjukkan bahwa suhu udara tidak berpengaruh nyata terhadap daya dukung iklim peternakan sapi potong di Pulau Enggano.Hal ini diduga karena suhu udara di Pulau Enggano terlalu tinggi. Menurut Hansen (2004) sapi yang berada di lingkungan udara panas, akan mengalami kesulitan dalam membuang panas hasil metabolisme dari tubuhnya ke udara di sekitarnya; apabila kondisi ini berlangsung dalam waktu yang cukup lama atau pada tingkatan cekaman panas yang tinggi, maka temperatur tubuh sapi akan meningkat dan sapi akan mengalami stress panas.

Berdasarkan model persamaan regresi linier dapat dijelaskan bahwa nilai $\beta$ sebesar 0,285 bernilai positif, hal tersebut menunjukkan bahwa semakin tinggi suhu udara, maka akan naik semakin tinggi pula tingkat daya dukung iklimnya terhadap perkembangan peternakan sapi potong, yaitu jika suhu udara naik $1^{0} \mathrm{C}$ lebih tinggi, maka tingkat daya dukung lingkungan atau presentase sapi potong yang berhasil diternakkan akan naik $0,285 \%$.

\section{Hubungan kelembaban udara terhadap daya dukung iklim untuk sapi potong \\ Pengaruh kelembaban udara} terhadap daya dukung iklim untuk peternakan sapi di Pulau Enggano dapat dilihat dari hasil perhitungan regresi linier ganda pada Tabel 5.berdasarkan hasil analisis regresi linier ganda dapat dilihat bahwa nilai $p$ sig $0,05=\alpha(0,0)$. Hal tersebut menunjukkan bahwa kelembaban udara berpengaruh nyata terhadap daya dukung iklim peternakan sapi potong di Pulau Enggano. Sejalan dengan hasil penelitian Setiawan (2013) bahwa bahwa kelembapan tidak berpengaruh signifikan terhadap daya dukung lingkungan peternakan sapi potong di Kecamatan Kerek.Berdasarkan model persamaan regresi linier dapat dijelaskan bahwa nilai $\beta$ sebesar 0,884 bernilai positif, hal tersebut menunjukkan bahwa semakin tinggi kelembaban udara, maka akan naik semakin tinggi pula tingkat daya dukung iklimnya terhadap perkembangan peternakan sapi potong, yaitu jika kelembaban udara naik $1 \%$ lebih tinggi, maka tingkat daya dukung lingkungan atau prosentase sapi potong yang berhasil diternakkan akan naik 0,884\%.

\section{Hubungan lama penyinaran terhadap daya dukung iklim untuk sapi potong}

Pengaruh lama penyinaran matahari terhadap daya dukung iklim untuk peternakan sapi di Pulau Enggano dapat dilihat dari hasil perhitungan regresi linier ganda pada Tabel 5. Berdasarkan hasil analisis regresi linier ganda dapat dilihat bahwa nilai p sig $0,038<\alpha(0,05)$. Hal tersebut menunjukkan bahwa lama penyinaran matahari berpengaruh nyata 
Tabel 5. Hasil analisis regresi hubungan iklim dan populasi sapi di Pulau Enggano Kabupaten Bengkulu Utara

\begin{tabular}{lcccccc}
\hline \multirow{2}{*}{ Model } & \multicolumn{2}{c}{$\begin{array}{c}\text { Unstandardized } \\
\text { Coefficients }\end{array}$} & $\begin{array}{c}\text { Standardized } \\
\text { Coefficients }\end{array}$ & t & Sig. \\
\cline { 2 - 4 } & $\mathrm{B}$ & Std. Error & Beta & & \\
\hline (Constant) & -15538.74 & 3056.834 & & & -5.083 & 0.037 \\
Suhu Udara $\left(\mathrm{X}_{1}\right)$ & 52.140 & 32.554 & 0.285 & 1.602 & 0.250 \\
Kelembaban Udara $\left(\mathrm{X}_{2}\right)$ & 139.945 & 32.361 & 0.884 & 4.324 & 0.050 \\
Lama Penyinaran Matahari $\left(\mathrm{X}_{3}\right)$ & 39.266 & 7.907 & 1.079 & & 4.966 & 0.038 \\
Curah Hujan $\left(\mathrm{X}_{4}\right)$ & 0.005 & 0.009 & 0.116 & 0.541 & 0.643 \\
Kecepatan Angin $\left(\mathrm{X}_{5}\right)$ & -1.338 & 7.651 & -0.030 & -0.175 & 0.877 \\
\hline
\end{tabular}

Dependent Variable: Populasi Sapi

terhadap daya dukung iklim peternakan sapi potong di Pulau Enggano.Berdasarkan model persamaan regresi linier dapat dijelaskan bahwa nilai $\beta$ sebesar 1,079 bernilai positif, hal tersebut menunjukkan bahwa semakin panjang lama penyinaran matahari, maka akan naik semakin tinggi pula tingkat daya dukung iklimnya terhadap perkembangan peternakan sapi potong, yaitu jika lama penyinaran matahari naik 1 satuan lebih tinggi, maka tingkat daya dukung lingkungan atau prosentase sapi potong yang berhasil diternakkan akan naik 1,079\%.

\section{Hubungan curah hujan terhadap daya dukung iklim untuk sapi potong}

Pengaruh curah hujan terhadap daya dukung iklim untuk peternakan sapi di Pulau Enggano dapat dilihat dari hasil perhitungan regresi linier ganda pada Tabel 5. Berdasarkan hasil analisis regresi linier ganda dapat dilihat bahwa nilai $\mathrm{p}$ sig $0,643>\alpha(0,05)$. Hal tersebut menunjukkan bahwa curah hujan tidak berpengaruh nyata terhadap daya dukung iklim untuk peternakan sapi potong di Pulau Enggano.

Berdasarkan model persamaan regresi linier dapat dijelaskan bahwa nilai $\beta$ sebesar 0,116 bernilai positif, hal tersebut menunjukkan bahwa semakin tinggi curah hujan, maka akan naik semakin tinggi pula tingkat daya dukung iklimnya terhadap perkembangan peternakan sapi potong, yaitu jika curah hujan naik naik $1 \mathrm{~mm}$ lebih tinggi, maka tingkat daya dukung lingkungan atau prosentase sapi potong yang berhasil diternakkan akan naik $0,116 \%$.

\section{Hubungan kecepatan angin terhadap daya dukung iklim untuk sapi potong}

Pengaruh kecepatan angin terhadap daya dukung iklim untuk peternakan sapi di Pulau Enggano dapat dilihat dari hasil perhitungan regresi linier ganda pada Tabel 5. Berdasarkan hasil analisis regresi linier ganda dapat dilihat bahwa nilai $\mathrm{p}$ sig $0,877>\alpha(0,05)$. Hal tersebut menunjukkan bahwa kecepatan angin tidak berpengaruh nyata terhadap daya dukung iklim peternakan sapi potong di Pulau Enggano. Sejalan dengan hasil penelitian Panjono dan Baliarti (2009) bahwa kecepatan angin tidak berpengaruh terhadap ternak sapi. Esmay dan Dixon (1986) menyatakan bahwa, ternak akan melakukan respon fisiologis terhadap lingkungan eksternal untuk mempertahankan temperatur tubuhnya.

Berdasarkan model persamaan regresi linier dapat dijelaskan bahwa nilai $\beta$ sebesar 0,030 bernilai negatif, hal tersebut menunjukkan bahwa semakin tinggi kecepatan angin, maka semakin rendah tingkat daya dukung iklimnya terhadap perkembangan peternakan sapi potong, yaitu jika kecepatan angin naik 1 knot lebih tinggi, maka tingkat daya 
dukung lingkungan atau prosentase sapi potong yang berhasil diternakkan akan naik $0,030 \%$.

\section{Faktor-faktor yang menopang iklim terhadap populasi sapi potong diPulau Enggano}

Berdasarkan hasil analisis regresi terlihat bahwa faktor-faktor utama yang menopang perkemabngan ternak sapi potong di Pulau Enggano adalah kelembaban udara dan lama penyinaran matahari dengan nilai significant masingmasing faktor adalah sebesar 0,05 dan 0,038. Sejalan dengan Collier dan Rosemarie (2007)bahwa faktor lingkungan seperti suhulingkungan dan kelembaban udara memilikiefek langsung terhadap produktivitas sapipotong sub tropis.

Kelembaban merupakan jumlah air dalam udara.Fungsi kelembaban udarasangat penting, karena mempengaruhi kecepatan kehilangan panas dari ternak.Lebih lanjut bahwa kelembaban dapat menjadi kontrol dari evaporasi kehilanganpanas melalui kulit dan saluran pernafasan.Kelembaban biasanya diekspresikan sebagai kelembaban relatif (Relative Humidity). Pada saat kelembaban tinggi, evaporasi terjadi secara lambat, kehilangan panas terbatas serta akhirnya dapat mempengaruhi keseimbangan termal ternak (Sientje 2003).

Tjasyono (2004) menambahkan bahwa kelembaban nisbi berpengaruh pada pernafasan dan keringat pada hewan.Udara yang sangat kering menyebabkan ketidaknyamanan ternak. Kelembaban nisbi rendah, angin dan suhu tinggi menyebabkan meningkatnya kebutuhan air untukternak. Kelembaban tinggi dapat berakibat langsung terhadap penurunan jumlah panas yang hilang akibat penguapan. Kelembaban tinggi mengakibatkan penguapan tertahan, sehingga akan meningkatkan panas pada sapi.

Radiasi matahari menyediakan hampir keseluruhan semua energi yang diterima oleh permukaan bumi. Sebagian radiasi matahari diserap langsung di dalam atmosfer akan tetapi kebanyakan diteruskan melewati atmosfer dan diserap oleh pemukaan bumi. Penyerapan ini memanaskan permukaan bumi dan menjadi sumber radiasi gelombang panjang.Radiasi matahari dalam perjalanannya melewati atmosfer menuju permukaan bumi mengalami penyerapan, pemantulan, hamburan dan pemancaran kembali (Prawirowardoyo, 1996).

Lama penyinaran matahari akan berpengaruh terhadap suplai hijauan sebagai pakan ternah. Cahaya matahari merupakan sumber utama bagi tanaman untuk melakukan proses fotosintesis. Semakin panjang lama penyinaran matahri maka akan berdampak pada semakin tinggi proses fotosintesis rumput, sehingga ketersediaan pakan bagi sapi potong semakin meningkat. Meningkatnya ketersediaan sapi potong akan menyebabkan membaiknya pertumbuhan sapi potong tesebut.

Lama penyinaran matahari akan berpengaruh terhadap aktivitas makhluk hidup, yaitu pada manusia, hewan, dan tumbuh-tumbuhan. Penyinaran yang lebih lama akan memberi kesempatan yang lebih besar pada tumbuhan untuk memanfaatkannya melalui proses fotosintesis.

\section{KESIMPULAN}

Berdasarkan hasil penelitian dan pembahasan dapat disimpulkan bahwa :

1. Hubungan tata luas lahan yang meliputi lahan sawah, sayuran, perkebunan, dan permukiman tidak berpengaruh terhadap populasi sapi potong di Pulau Enggano.

2. Faktor-faktor utama yang menopang populasi sapi potong di Pulau Enggano adalah kelembaban udara dan lama penyinaran matahari. Suhu udara, curah hujan, dan kecepatan angin tidak berpengaruh terhadap populasi sapi potong. 


\section{DAFTAR PUSTAKA}

Collier RJ, Rosemarie BZ. 2007. Heat stress effects on cattle: what we know and what we don't know. 22th Southwest Nutrition and Management Conference. February 22- 23. Department of Animal Sciences.The University of Arizona.

Esmay, M. L. 1982. Principle of Animal environmental. AVI Publishing Company, Inc. Wesport, Connecticut.

Esmay, M.L. and J.E. Dixon. 1986. EnvironmentalControl for Agricultural Buildings. The AVIPublishing Company, Inc. Westport,Connecticut.

Hansen. 2004. Physiological and cellularadaptations of zebu cattle to thermal stress.Anim Reprod Sci. 82-83:349-360

Juanda. B. 2002. Pertumbuhan ekonomi dan pergeseran structural dalam industrialisasi di Indonesia. J. Ekon., Vo.9. IPB., Bogor

Kadarsih, S. 2004. Performans Sapi bali berdasarkan ketinggian tempat di daerah transmigrasi Bengkulu : I Performans pertumbuhan. Jurnal Ilmu-Ilmu Pertanian 6 (1): 50-56

Matondang, Sitepu, dan Thalib. 1998. Analisis faktor-faktor produksi sapi potong di Lampung. Seminar Nasional Peternakan dan Veteriner.

McDowell, R. E. 1974. The environment versus man and his animals. In: H.H. Cole \& M. Ronning (Eds.). Animal Agriculture. W.H. Freeman and Co., San Fransisco

Musriadi.2013. Pulau Enggano diproyeksi sentra peternakan sapi. Antara Bengkulu.com. http://www.antarabengkulu.com/be rita/20702/pulau-engganodiproyeksi-sentra peternakan-sapi

Pane, W.J.A. 1970. Catle Production in The Tropics. Vol. 1. Longman London

Panjono dan Baliarti. 2009. Pengaruh buka-tutup kandang terhadap kenyamanan dan kinerjaproduksi sapi peranakan ongole. Buletin Peternakan Vol. 33(2): 106-110

PrawirowardoyoS.1996.Meteorologi.Pener bit ITB:Bandung

Saragih, B. 2000.Agribisnis berbasis peternakan.Kumpulan pemikiran. USESE Foundation dan Pusat Studi Pembangunan IPB, Bogor

Setiawan.2013. Kajian Daya Dukung Lingkungan Untuk Peternakan Sapi Potong di Kecamatan Kerek Kabupaten Tuban. http://webcache.googleusercontent.co $\mathrm{m} / \mathrm{search}$ ?q=cache:GmbBqP2J1LoJ: jurnalmahasiswa.unesa.ac.id/article /10342/40/article.pdf $+\& c d=1 \& h l=i$ $\mathrm{d} \& \mathrm{ct}=\mathrm{clnk} \& \mathrm{gl}=\mathrm{id}$. Diakses pada 12 Januari 2018

Sientje. 2003. Stress panas pada sapi perah laktasi. IPB, Bogor

Silanikove, N. 2000. Review: The Physiological Basis of Adaptation in Goats to Harsh Environments. Small Ruminant Research 35 (2000) 181-193

Tjasyono, B., 2004. Klimatologi.Penerbit ITB. Bandung Payne, W.J.A. 1990. An Introduction of Animal Husbandry in The Tropics. $4^{\text {th }}$ ed.Tropical agriculture series.Longman Scientific and technical. Copublish inthe united states with Jihn Wiley \& Sons, Inc. New York 